\title{
A Quantitative Assessment of the Diet of the Blue Shark (Prionace glauca) off Nova Scotia, Canada
}

\author{
Meaghen E. McCord and Steven E. Campana \\ Marine Fish Division, Fisheries and Oceans Canada \\ Bedford Institute of Oceanography, P. O. Box 1006, Dartmouth, Nova Scotia B2Y 4A2
}

\begin{abstract}
A quantitative analysis of the stomach contents of blue sharks (Prionace glauca) caught in recreational shark fishing tournaments in Nova Scotia, Canada tested for dietary differences based on sex, maturity and tournament location across 3 sampling years (1999-2001). Of 706 sharks examined, 303 stomachs (43\%) were everted, 131 (19\%) were empty, 231 (33\%) contained food items and 41 stomachs $(5 \%)$ were not examined. Pelagic teleosts and groundfish were found in $19 \%$ and $14 \%$ of examined blue shark stomachs, respectively. Stomach fullness did not differ between sexes or maturity category. Differences existed between the diet of immature and mature males as well as between immature females and immature males, suggesting sexual segregation during feeding. The frequency of occurrence of pelagic teleosts and groundfish changed across sampling years. Blue sharks off Nova Scotia appear to be opportunistic predators, consuming a wide range of fish species, mammalian tissues and inanimate objects.
\end{abstract}

Keywords: dietary differences, groundfish, Nova Scotia, pelagic teleosts, Prionace glauca, recreational shark fishery, stomach contents

\section{Introduction}

Blue shark (Prionace glauca) distribution and seasonal movements have been thoroughly studied in other parts of the world, but little is known about the feeding habits of these sharks or their role as predators in the epipelagic environment (Tricas, 1979). The diet of blue sharks is reported to consist primarily of cephalopods and pelagic fish but they appear to be opportunistic predators, feeding on a variety of prey items (Cortés, 1999). Nothing is known of blue shark diet in the waters off eastern Canada despite the fact that it is a common bycatch species in certain commercial fisheries (Campana et al., MS 2002). Although commercially caught blue sharks are seldom available for biological examination; recreational shark tournaments land several hundred blue sharks each year. The goal of this study was to provide a quantitative analysis of the stomach contents of blue sharks caught in the recreational shark fishery in Nova Scotia, Canada.

\section{Materials and Methods}

Blue shark stomachs were collected between 1999 and 2001 from sharks landed at annual shark fishing tournaments held in Nova Scotia during the summer months (July-September) (Table 1; Fig. 1). All sharks were caught by tournament participants using rod and reel. The average time interval between shark capture and examination was 4 to 5 hours. Upon return to the wharf, all sharks were weighed and measured, sex determined and sexual maturity assessed. All lengths were recorded as fork lengths measured over the curve of the body. Stomachs of sharks landed round (ungutted) were felt by hand to determine if any contents were present. If contents could be felt by hand then the stomach was excised $(n=365)$. The stomach was removed by cutting above the oesophageal sphincter and below the pyloric sphincter as well as through the connective tissue. Sharks in some tournaments were landed dressed with the stomachs having been removed by tournament participants prior to docking $(n=341)$. The oesophageal and pyloric sphincters were tied off by derby participants and given to tournament monitors, with stomach contents still contained in the stomach. Stomach excisions by the tournament participants appeared to be an acceptable method of stomach extraction, as participants were shown the proper method for stomach extraction by biologists prior to the tournament and most stomachs extracted by participants were returned intact, with little or no obvious damage.

The state of sexual maturity was categorized as either immature or mature. Maturity of male blue sharks was determined by feeling the claspers by hand. 
TABLE 1. Summary table of blue shark catches at Nova Scotia tournaments.

\begin{tabular}{|c|c|c|c|c|c|c|}
\hline Tournament & Date & $\begin{array}{c}\text { No. } \\
\text { Examined }\end{array}$ & $\begin{array}{c}\mathrm{FL}^{1} \\
\text { (Range) }\end{array}$ & $\begin{array}{l}\text { Landed } \\
\text { Dressed } \\
\text { or Round }\end{array}$ & $\begin{array}{l}\text { Immature } \\
\mathrm{M} / \mathrm{F}\end{array}$ & $\begin{array}{c}\text { Mature } \\
\mathrm{M} / \mathrm{F}\end{array}$ \\
\hline \multicolumn{7}{|l|}{ Brooklyn } \\
\hline 2001 & 25-26 August & 37 & $146-280$ & Round & $9 / 17$ & $6 / 5$ \\
\hline \multicolumn{7}{|l|}{ Dartmouth } \\
\hline 1999 & 7 August & 89 & $129-238$ & Dressed & $16 / 11$ & $7 / 0$ \\
\hline 2000 & 12 August & 32 & $147-267$ & Dressed & $10 / 2$ & $15 / 0$ \\
\hline \multicolumn{7}{|l|}{ Eastern Shore } \\
\hline 2001 & 28 July & 63 & $160-270$ & Round & $8 / 38$ & $17 / 0$ \\
\hline \multicolumn{7}{|l|}{ Lockeport } \\
\hline 1999 & 7 Agust & 80 & $147-244$ & Dressed & $0 / 0$ & $0 / 0$ \\
\hline 2000 & 12-13 August & 105 & $145-249$ & Dressed & $17 / 33$ & $44 / 3$ \\
\hline 2001 & 11-12 August & 13 & $150-238$ & Dressed & $0 / 0$ & $0 / 0$ \\
\hline \multicolumn{7}{|l|}{ Split Crow } \\
\hline 1999 & 12 September & 31 & $153-270$ & Round & $9 / 1$ & $21 / 0$ \\
\hline 2000 & 10 September & 29 & $178-274$ & Dressed & $6 / 1$ & $22 / 0$ \\
\hline \multicolumn{7}{|l|}{ Yarmouth } \\
\hline 1999 & 21-22 August & 110 & $151-269$ & Round & $28 / 0$ & $51 / 0$ \\
\hline 2000 & 19-20 August & 79 & $159-276$ & Round & $17 / 6$ & $52 / 1$ \\
\hline 2001 & 19August & 38 & $153-265$ & Round & $2 / 24$ & $10 / 0$ \\
\hline Totals & & 706 & & & $122 / 133$ & $245 / 9$ \\
\hline
\end{tabular}

${ }^{1} \mathrm{FL}$ : fork length $(\mathrm{cm})$ measured over the curve of the body.

If the claspers were heavily calcified, rotated freely at the base and the rhipidion could be fully opened, the male was considered to be mature (Clark and von Schmidt, 1965). Maturity of female blue sharks was determined by examining the uterus and shell (oviducal) gland. If the uteri were significantly wider than the oviducts and the oviducal glands were enlarged, the female was considered to be mature (Pratt, 1979; Hazin et al., 1994).

Total stomach content volume was determined by measuring the stomach contents in a 2-litre graduated pail. Blue shark stomachs were considered full if they contained at least one food item. All prey items were then identified to the lowest possible taxon and counted. Food items were grouped into one of 10 categories. If prey items were unidentifiable, they were grouped into the prey categories "unidentified teleost", "unidentified vertebrate", "unidentified remains" or "miscellaneous biological". Miscellaneous biological material included feathers from unidentified birds and algae. Items typically used as bait (herring, mackerel, Atlantic salmon) and included in volumetric determinations of stomach contents were excluded from the analysis. These were identified by obvious knife cuts and hook marks as well as by an undigested appearance.

Frequency of occurrence (the percentage of stomachs containing a specific prey item, $F_{0}$ ) was recorded for major forage categories (Hyslop, 1980) and compared among blue shark sex and maturity groupings. Additionally, frequency of occurrence of major forage categories was compared among tournament locations and years.

In 2002, stomach capacity was measured in 77 blue shark stomachs from recreational shark fishing tournaments. Stomach capacity was measured by tying off the stomach at the pyloric sphincter and then filling each stomach with water using a 2-litre graduated pail until the point at which water began flowing over the top. 

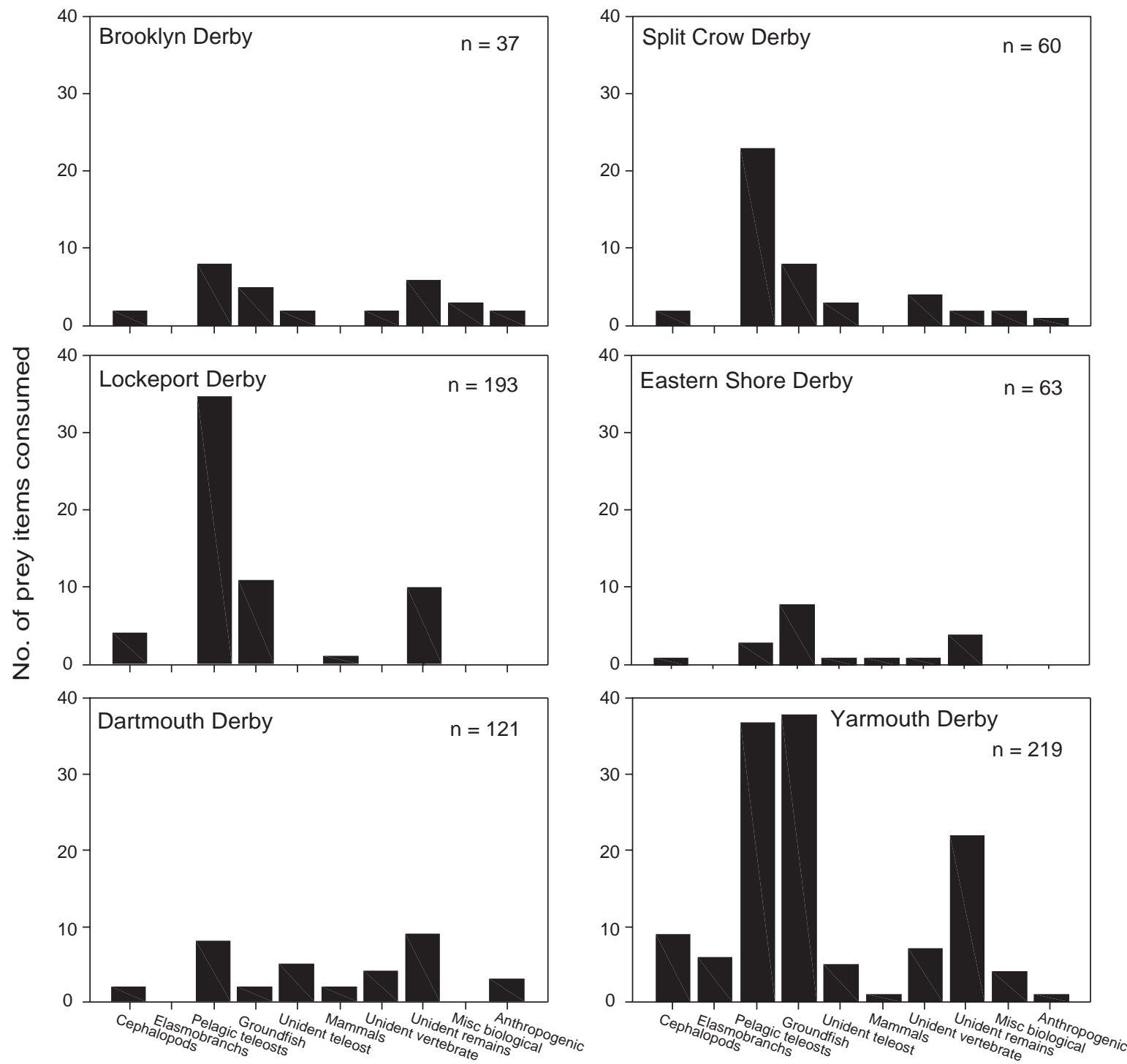

\section{Major prey category}

Fig. 1. The total number of prey items consumed by blue sharks per major prey category according to tournament.

\section{Results}

Of the blue sharks landed round $(n=365), 40 \%$ of the stomachs contained food. Of the blue sharks landed dressed $(n=341), 37 \%$ contained food. Stomachs containing food items were taken from 154 males $(152-280 \mathrm{~cm})$ and 77 females $(145-231 \mathrm{~cm})$, from a total of 132 immature sharks and 108 mature sharks. Forty-two additional stomachs for which either sex or maturity was not recorded were included in the total sample summaries only. A total of 11 families and 14 species were identified among the stomach items (Table 2).
The percentage of full stomachs did not differ between males and females (37\%). Mature males had a higher percentage of full stomachs $(41 \%)$ than immature males (32\%), although this difference was not significant. Sixty-seven percent of immature females had a full stomach, while $50 \%$ of mature females had a full stomach. Again, this difference was not significant.

Pelagic teleosts constituted the most frequently observed prey category with a category total frequency of $18.8 \%$ (Table 2). Within this prey category, Atlantic mackerel were most frequently consumed $\left(F_{0}=13.3\right)$. 
TABLE 2. Prey items and major prey categories found in 452 blue shark stomachs sampled off Nova Scotia, Canada. A Total of 273 stomachs contained food items while 131 were empty.

\begin{tabular}{|c|c|c|c|c|c|}
\hline Prey category & & $\begin{array}{l}\text { No. of } \\
\text { items }\end{array}$ & $\begin{array}{l}\text { No. of stomachs } \\
\text { with food item }\end{array}$ & $\begin{array}{l}\text { Frequency of } \\
\text { occurrence }\left(F_{0}\right) \\
\quad(\%)\end{array}$ & $\begin{array}{c}\text { Category } \\
\text { Total } \\
F_{0} \\
(\%)\end{array}$ \\
\hline Cephalopods & Unknown squid & 20 & 19 & 4.20 & 4.20 \\
\hline $\begin{array}{l}\text { Elasmobranchs } \\
\text { Squalidae } \\
\text { Rajidae }\end{array}$ & $\begin{array}{l}\text { Unknown dogfish } \\
\text { Unknown skate }\end{array}$ & $\begin{array}{l}6 \\
1\end{array}$ & $\begin{array}{l}6 \\
1\end{array}$ & $\begin{array}{l}1.33 \\
0.22\end{array}$ & \\
\hline $\begin{array}{l}\text { Pelagic (teleosts) } \\
\text { Clupeidae } \\
\text { Salmonidae } \\
\text { Scomberesocidae } \\
\text { Scombridae }\end{array}$ & $\begin{array}{c}\text { Herring (Clupea harengus) } \\
\text { Atlantic salmon (Salmo salar) } \\
\text { Atlantic saury (Scomberesox saurus) } \\
\text { Atlantic mackerel (Scomber scombrus) }\end{array}$ & $\begin{array}{r}34 \\
1 \\
2 \\
80\end{array}$ & $\begin{array}{r}22 \\
1 \\
2 \\
60\end{array}$ & $\begin{array}{r}4.87 \\
0.22 \\
0.44 \\
13.27\end{array}$ & 18.80 \\
\hline $\begin{array}{l}\text { Groundfish } \\
\text { (teleosts) } \\
\text { Cyclopteridae } \\
\text { Gadidae }\end{array}$ & $\begin{array}{c}\text { Lumpfish (Cyclopterus lumpus) } \\
\text { Atlantic cod (Gadus morhua) } \\
\text { Haddock (Melanogrammus aeglefinus) } \\
\text { Hake (Merluccius albidis) } \\
\text { Monkfish (Lophius americanus) } \\
\text { Unknown flounder } \\
\text { Redfish (Sebastes fasciatus) }\end{array}$ & $\begin{array}{r}50 \\
9 \\
3 \\
1 \\
5 \\
1 \\
3\end{array}$ & $\begin{array}{r}43 \\
9 \\
1 \\
1 \\
5 \\
1 \\
3\end{array}$ & $\begin{array}{r}13.93 \\
9.51 \\
1.99 \\
0.22 \\
0.22 \\
1.11 \\
0.22 \\
0.66\end{array}$ & \\
\hline $\begin{array}{l}\text { Unidentified } \\
\text { teleosts }\end{array}$ & & 15 & 15 & 3.32 & 3.32 \\
\hline Mammals & $\begin{array}{c}\text { unknown seal } \\
\text { unidentified tissue }\end{array}$ & $\begin{array}{l}2 \\
3\end{array}$ & $\begin{array}{l}2 \\
3\end{array}$ & $\begin{array}{l}0.44 \\
0.66\end{array}$ & 1.10 \\
\hline $\begin{array}{l}\text { Unidentified } \\
\text { vertebrate }\end{array}$ & Unidentified vertebrae & 17 & 14 & 3.10 & 3.10 \\
\hline $\begin{array}{l}\text { Unidentified } \\
\text { remains }\end{array}$ & & 52 & 50 & 11.06 & 11.06 \\
\hline $\begin{array}{l}\text { Misc. biological } \\
\text { material }\end{array}$ & $\begin{array}{c}\text { Unknown feathers } \\
\text { algae }\end{array}$ & $\begin{array}{l}3 \\
6\end{array}$ & $\begin{array}{l}3 \\
6\end{array}$ & $\begin{array}{l}0.66 \\
1.33\end{array}$ & 1.99 \\
\hline $\begin{array}{l}\text { Anthropogenic } \\
\text { material }\end{array}$ & $\begin{array}{l}\text { cans } \\
\text { other }\end{array}$ & $\begin{array}{l}4 \\
3\end{array}$ & $\begin{array}{l}4 \\
2\end{array}$ & $\begin{array}{l}0.89 \\
0.44\end{array}$ & 1.33 \\
\hline Total & & 321 & & & \\
\hline
\end{tabular}

Groundfish were also frequently observed with a category total frequency of $13.9 \%$. Within this prey category, lumpfish were most frequently consumed $\left(F_{0}\right.$ $=9.5$ ).

Frequencies of occurrence of the major prey categories differed between immature and mature males (Table 3). Groundfish formed the majority of the diet of mature males $\left(F_{0}=12.96\right)$ while for immature males, after unidentified remains $\left(F_{0}=\right.$
9.70), pelagic teleosts formed the majority of the diet $\left(F_{0}=8.96\right)$.

Frequencies of occurrence of the major prey categories differed between immature and mature females (Table 3). Pelagic teleosts formed the majority of the diet of immature females $\left(F_{0}=27.94\right)$, followed by groundfish $\left(F_{0}=10.29\right)$. Elasmobranchs, pelagic teleosts, groundfish, unidentified teleosts and unidentified vertebrates constituted an equal 
TABLE 3. Frequency of occurrence $\left(\mathrm{F}_{0}\right)$ of major prey categories by blue shark sex and maturity category: a total of 344 male shark stomachs (134 male shark stomachs (134 immature and 270 mature) were sampled of which 154 were full and 91 were empty, a total of 130 female shark stomachs (136 immature and 9 mature) were sampled of which 77 were full and 40 were empty.

\begin{tabular}{|c|c|c|c|c|c|c|}
\hline \multirow[b]{2}{*}{ Prey Category } & \multicolumn{3}{|c|}{ Immature } & \multicolumn{3}{|c|}{ Mature } \\
\hline & No. items & $\begin{array}{c}\text { No. of Stomachs } \\
\text { with food items }\end{array}$ & $F_{0}(\%)$ & $\begin{array}{l}\text { No. of } \\
\text { Items }\end{array}$ & $\begin{array}{l}\text { No. of Stomachs } \\
\text { with Food Items }\end{array}$ & $F_{0}(\%)$ \\
\hline \multicolumn{7}{|c|}{ Male } \\
\hline Cephalopods & 9 & 8 & 5.97 & 7 & 7 & 2.59 \\
\hline Elasmobranchs & 1 & 1 & 0.75 & 5 & 5 & 1.85 \\
\hline Pelagic teleosts & 14 & 12 & 8.96 & 39 & 30 & 11.11 \\
\hline Groundfish & 13 & 11 & 8.21 & 43 & 35 & 12.96 \\
\hline Unidentified teleosts & 2 & 2 & 1.49 & 9 & 8 & 2.96 \\
\hline Mammals & 2 & 2 & 1.49 & 9 & 8 & 2.96 \\
\hline Unidentified vertebrate & 2 & 2 & 1.49 & 2 & 2 & 0.74 \\
\hline Unidentified remains & 15 & 13 & 9.70 & 23 & 23 & 8.52 \\
\hline Misc. biological material & 1 & 1 & 0.75 & 3 & 3 & 1.11 \\
\hline Anthropogenic material & 3 & 1 & 0.75 & 3 & 2 & 0.74 \\
\hline \multicolumn{7}{|c|}{ Female } \\
\hline Cephalopods & 4 & 4 & 2.94 & 0 & 0 & 0.0 \\
\hline Elasmobranchs & 0 & 0 & 0.0 & 1 & 1 & 11.11 \\
\hline Pelagic teleosts & 63 & 38 & 27.94 & 1 & 1 & 11.11 \\
\hline Groundfish & 14 & 14 & 10.29 & 2 & 1 & 11.11 \\
\hline Unidentified teleosts & 3 & 3 & 2.21 & 1 & 1 & 11.11 \\
\hline Mammals & 1 & 1 & 0.74 & 0 & 0 & 0.0 \\
\hline Unidentified vertebrate & 5 & 4 & 2.94 & 1 & 1 & 11.11 \\
\hline Unidentified remains & 14 & 13 & 9.56 & 0 & 0 & 0.0 \\
\hline Misc. biological material & 5 & 5 & 3.68 & 0 & 0 & 0.0 \\
\hline Anthropogenic material & 1 & 1 & 0.74 & 0 & 0 & 0.0 \\
\hline Total stomachs examined & & 83 & & & 5 & \\
\hline
\end{tabular}

percentage of the diet of mature females (11.1\%). No other prey categories were recorded for mature females.

Differences in stomach fullness were found to exist between tournaments, ranging from $6 \%$ to $100 \%$. The highest percentage of female blue sharks with full stomachs was recorded at the Yarmouth tournament; $100 \%$ of mature females $(n=1)$ and $93 \%$ of immature females $(n=10)$, respectively. The highest percentage of males with full stomachs were recorded at the Lockeport tournament $(68 \%$ of mature males; $n=44)$ and Yarmouth tournament (53\% of immature males; $n=113$ ), respectively.

The number of prey items consumed from several major prey categories differed between tournaments (Fig. 1), with the highest number of pelagic teleosts, groundfish and unidentified remains found at the southernmost tournament (Yarmouth).

The number of prey items consumed from several major prey categories differed between years (Fig. 2), with an increase in number of pelagic teleosts and groundfish in 1999, and a substantial increase in the number of pelagic teleosts between 1999 and 2000. The occurrence of the major prey categories also differed between sexes across years, with the number of elasmobranchs, groundfish and unidentified remains being highest in male blue shark stomachs between 1999 and 2001 .

Of the 77 blue shark stomachs collected for which stomach capacity was measured, the mean stomach capacity was $10.2 \pm 0.7$ liter. The range of stomach capacities was $0.3 \mathrm{~L}$ to 29.5 liter. Of those 77 blue 


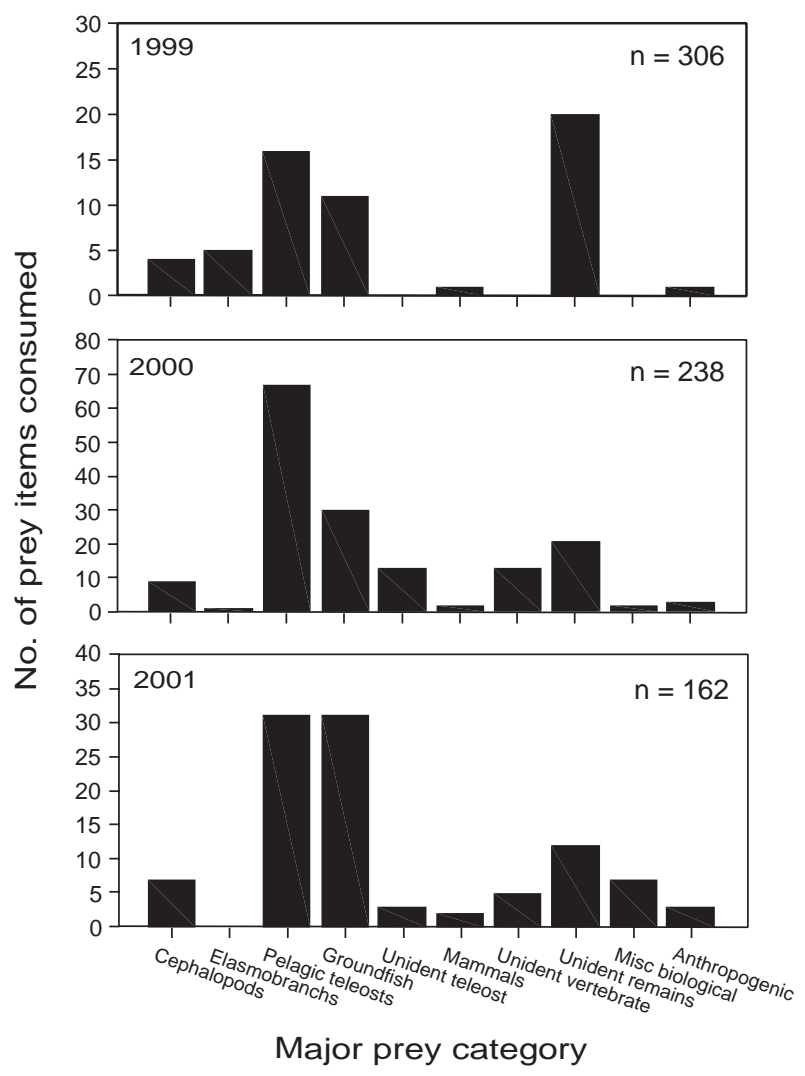

Fig. 2. The total number of prey items consumed by blue sharks per major prey category according to year.

shark stomachs, 19 contained food items with a mean stomach content volume of $0.36 \pm 0.10$ liter. The range of stomach content volumes was 0.01 to 1.6 litres. The average fullness of these 77 blue shark stomachs was calculated to be $28.5 \%$.

\section{Discussion}

This is the first quantitative examination of blue shark stomach contents in the Northwest Atlantic. Our results indicate that blue sharks off Nova Scotia feed primarily on pelagic teleosts (i.e.,clupeids and scombrids). Groundfish (i.e. cyclopterids and gadids) also constitute an important component of blue shark diet in this region. Pelagic teleosts and groundfish made up most of the diet of immature and mature males, while immature females tended to consume more pelagic teleosts than mature females. It seems likely that the contents of blue shark stomachs examined in the tournaments only reflect a portion of the actual diet of the sharks since tournaments were limited to the summer months. Thus it was not possible to determine whether, or how much, the frequency of occurrence of the major prey items varies seasonally.

The results of our dietary analysis of blue sharks may have been influenced by several factors associated with recreational shark fishing. According to Stevens (1973), sharks caught in the recreational fishery may vomit their food while being played on a rod and reel, suggesting that the observed proportion of blue sharks with empty stomachs may be higher than the actual number. Blue shark stomachs were found to be empty $19 \%$ of the time, a percentage that is lower than that found in some studies on the stomach contents of blue sharks (Strasburg, 1958; Stevens, 1973) and not substantially higher than the $15.3 \%$ observed by Harvey (1989). Since digestion may still occur between the period of capture and the period of stomach removal, the number of observed empty stomachs may again be greater than the actual number, although complete digestion of prey items may take 12-24 hours (Tricas, 1979). Also, since the digestion time of prey varies according to the relative digestibility of the parts of the prey (Stevens, 1973), it is possible that the frequency of occurrence of prey with short periods of relative digestibility (e.g. invertebrates) were underestimated. Furthermore, since sharks were caught on baited hooks, it is possible that hungry sharks were more likely to be caught than sharks that were not hungry. This possibility is supported by the fact that blue shark stomachs sampled in 2002 were, on average, only $28.5 \%$ full. The stomachs of blue sharks will sometimes become everted when the shark is weighed. However since sharks in this study were weighed alongside the dock it was possible to retrieve any food remains from sharks sampled with everted stomachs.

Other studies that examined the stomach contents of blue sharks discovered that cephalopods constituted an important component of their diet (Casey, 1982; Tricas, 1979; Vas, 1990). Our study did not find many cephalopods in the stomachs of blue sharks. This may be due to a seasonal factor or perhaps because cephalopods were not particularly abundant in the nearshore regions of Nova Scotia.

Differences in the frequency of occurrence of major prey categories across tournament areas were minor although some substantial differences were found in the frequency of occurrence of groundfish. This may indicate a geographic shift in the diet of the blue sharks as they move up the coast from the southern tip of Nova Scotia to more northerly waters 
around Halifax. Vas (1990) suggested that blue sharks exhibit prey switching according to the most common prey species found in their surrounding waters. A spatial shift in diet during the sampling period of 1999 to 2001 may indicate a change in prey species composition, such as a change in the relative abundance of potential prey items along the shores of Nova Scotia. Since the available prey spectrum has not been analyzed, it is impossible to determine whether this shift is due to prey selectivity by blue sharks or actual changes in prey species composition.

The occurrence of miscellaneous biological materials (e.g. feathers) and anthropogenic material (e.g. plastic bags, cans) indicates that blue sharks consume virtually anything of appropriate size in the water column. Since the occurrence of these items was relatively infrequent, it is likely that their consumption was accidental. Stomachs of other shark species have also been found to contain inorganic items such as stone and plastic wrapping (Joyce et al., 2002; Stillwell and Kohler, 1982).

By examining stomach contents according to blue shark sex and maturity across years and areas, we determined that dietary differences exist between male and female sharks as well as between immature and mature sharks. Dietary differences between sexes and maturity groups may exist due to segregation caused by differing habits, including feeding behaviour (Strasburg, 1958). Since immature males and females consumed more pelagic teleosts than mature sharks, it is possible that they feed higher in the water column. Alternatively, this may be due to the fact that the pelagic teleosts found in the stomachs of immature sharks tended to be smaller than other potential prey items and thus easier to consume. This segregation may also explain why fewer females were caught during the tournaments.

Blue sharks are one of the most abundant and widely distributed shark species (Carey and Scharold, 1990; O'Boyle et al., 1996; Campana et al., MS 2002). Thus it is thought that their foraging may affect commercially important fish stocks, although the actual impact is not known (Harvey, 1989). Further assessments of the diet of blue sharks in the Northwest Atlantic will allow us to determine the extent to which these sharks exhibit selective feeding as well as the foraging pressure they exert on commercially important fish species.

\section{References}

CAMPANA, S., P. GONZALEZ, W. JOYCE, and L. MARKS. MS 2002. Catch, bycatch and landings of blue shark (Prionace glauca) in the Canadian Atlantic. DFO Can. Sci. Advis. Sec. Res. Doc., 2002/101.

CAREY, F. G., and J. V. SCHAROLD. 1990. Movements of blue sharks (Prionace glauca) in depth and course. Mar Biol., 106(3): 329-342.

CASEY, J. G. 1982. Blue shark, Prionace glauca, synopsis. Ecology of the Middle Atlantic Bight (fish and shellfish) - Monograph 15, Fish Distribution, MESA New York Bight Atlas, New York Sea Grant Inst., Albany, N. Y. MD Grosslein and T Azarovitz (eds): p. 45-48.

CLARK, E., and K. VON SCHMIDT. 1965. Sharks of the central Gulf Coast of Florida. Bull. Mar. Sci., 15(1): 1383.

CORTÉS, E. 1999. Standardized diet compositions and trophic levels of sharks. ICES J. Mar. Sci., 56: 707-717.

HARVEY, J. T. 1989. Food habits, seasonal abundance, size, and sex of the blue shark, Prionace glauca, in Monterey Bay, California. Calif. Fish and Game, 75(1): 33-44.

HAZIN, F. H. V., C. E. BOECKMAN, E. C. LEAL, R. P. T. LESSA, K. KIHARA, and K. OTSUKA. 1994. Distribution and relative abundance of the blue shark, Prionace glauca, in the southwestern equatorial Atlantic Ocean. Fish. Bull., 92: 474-480.

HYSLOP, E. J. 1980. Stomach contents analysis - a review of methods and their application. J. Fish. Biol., 17: 411429.

JOYCE, W., S. E. CAMPANA, L. J. NATANSON, N. E. KOHLER, H. L. PRATT Jr., and C. F. JENSEN. 2002. Analysis of stomach contents of the porbeagle shark (Lamna nasus) in the Northwest Atlantic. ICES J. Mar. Sci., 59(6): 1263-1269.

O'BOYLE, R. N., G. M. FOWLER, P. C. F. HURLEY, M. A. SHOWELL, W. T. STOBO, and C. JONES. MS 1996. Observations on Blue Shark (Prionace glauca) in the North Altlantic, DFO Atl. Fish. Res., Doc. 96/25.

PRATT, H. L., Jr. 1979. Reproduction in the blue shark, Prionace glauca. Fish Bull., 77(2): 445-470.

STEVENS, J. D. 1973. Stomach contents of the blue shark (Prionace glauca L.) off south-west England. J. Mar. Biol. Assoc. U.K., 53: 357-361.

STILLWELL, C. E., and N. E. Kohler. 1982. Food, feeding habits, and estimates of daily ration of the shortfin mako (Isurus oxyrinchus) in the northwest Atlantic. Can. J. Fish. Aquat. Sci., 39: 407-414.

STRASBURG, D. W. 1958. Distribution, abundance, and habits of pelagic sharks in the central Pacific Ocean. Fish Bull., 58(138): 335-361.

TRICAS, T. C. 1979. Relationships of the blue shark, Prionace glauca, and its prey species near Santa Catalina Island, California. Fish Bull., 77(1): 175-182.

VAS, P. 1990. The abundance of the blue shark, Prionace glauca, in the western English Channel. Environ. Biol. Fishes, 29: 209-225. 